\title{
RESEARCHPAPER
}

\section{Isolation, partial purification, product formation and characterization of $\beta$ - glucosidase from roots of Hordeum vulgare $\mathrm{L}$.}

\author{
SUMAN TIWARI, O. P. VERMA AND SHRUTI SHUKLA
}

Department of Molecular and Cellular Engineering, Jacob School of Biotechnology and Bio-Engineering, Sam Higginbottom Institute of Agriculture, Technology and Sciences, ALLAHABAD (U.P.) INDIA

Email : tiwarisuman19@gmail.com

Article Info :Received : 02.12.2015; Revised : 09.01.2016; Accepted : 07.02.2016

$\beta$-glucosidase (EC 3.2.1.21) was extracted from roots of Hordeum vulgare and was purified using ammonium sulphate fractional precipitation and sephadex G-25 chromatography. The molecular weight of enzyme was found in the range of 17-54KDa. The enzyme $\beta$-glucosidase has optimum $\mathrm{pH} 5.0$ and the optimum temperature was found at $60^{\circ} \mathrm{C}$. Bioethanol was produced from roots of Hordeum vulgare.

Key words: Hordeum vulgare, $\beta$-Glucosidase, Purification, Characterization

How to cite this paper : Tiwari, Suman, Verma, O.P. and Shukla, Shruti (2016). Isolation, partial purification, product formation and characterization of $\beta$ - glucosidase from roots of Hordeum vulgare L. Asian J. Bio. Sci., 11 (1) : $52-55$ [Special Issue of AFBSAH-2016]. 